\title{
National typeface in Poland between the wars: drawing typographic boundaries
}

\author{
Agata Szydłowska
}

type design, national identity, Poland, roman typeface
In 1918 when Poland recouped its independence, a creation of national styles in art and design started to be an important political issue for a newly created nation state. A special consideration was given to inventing a national typeface. After numerous discussions between designers, artists, publishers and typographers, a complete "Polish typeface" was proposed by Adam Półtawski who decided to elaborate it based on a specificity of Polish language. Comparing the ways in which typefaces are given national meanings with other cases from Western Europe (Blackletter in Germany and Gaelic typefaces in Ireland), the article discusses the ways in which creation of the national typeface from scratch helps to integrate a national community while at the same time excluding different ethnic groups.

\section{Introduction}

A quest for a national typeface has defined the first decades of Polish modern type design. In 1918, by virtue of the Treaty of Versailles, Poland, along with some other nations from the Central Europe, has gained independence after more than 130 years of being divided between three foreign powers: Russia, Prussia and Austria-Hungary. The political and cultural climate of celebrating unique national identities was prevailing back these days in the region. Nationalisms coincided with an intense modernisation as the newly founded states were not only keen to demonstrate their progressiveness but also to catch up with the ideas of both material and civilizational progress. Art historian Andrzej Szczerski argues that the alliance between nationalism and modernity was a characteristic trait of Central European nations between the wars:

"(...) instead of an indisputable application of any ready-made models of modernity, they [i.e. the nations] strived to elaborate original concepts of modernising reforms basing not only on a democratic nationalism, but also on an attempt to bring together modernity with traditional values which the particular nations regarded as worth preserving. (...) Modernisation didn't mean though abandoning of neo-romantic ideas of national revival and some radical changes were performed often in the name of slogans which mythologised cultural uniqueness which were proclaimed also by the leading figures of the avant-garde" (Szczerski 2010, p. 7).

National revival in Polish architecture and design was anything but new (Chmielewska 2006; Crowley 1992; Crowley 2001; Jedlicki 1991, 
1 The connection between Polish romanticism and ideas of Johann Gottfried Herder is not direct or obvious. However the idea that a folk was a bearer of a naturalised, organic national identity and that this identity is strongly connected with a national language are common for the Polish romanticists and Herder's idea of primordialism. et al.). Inspired by the Arts and Crafts movement and romantic ideas resembling of Johann Gottfried Herder's primordialism ${ }^{1}$ (GimenoMartínez 2016, pp.33-46), the ideas were vivid from the second half of 19th century. They manifested mainly within the spectre of vernacularism. After 1918 the urge to create in a specific national style (whatever it meant) was not only a matter of preserving national identity but also of presenting Poland as a modern country with a unique cultural identity. Creating a separate style was important in the context of an unstable political situation of Poland. Artists and intellectuals argued that in order to maintain its borders from 1918, Poland needed to emphasise its distinctiveness both on a political and artistic level. Therefore a national style could be an element of cultural diplomacy: in the international arena it could testify that the country "deserves independence" (Jedlicki 1991, p.33). Moreover, a national style could be a tool, which helped to culturally integrate areas, which, until 1918, had been parts of three different states. Polish intelligentsia believed that integrating these three extremely different terrains was only possible if common foundations of a national culture were created. In this article I will argue that in the case of national typeface, the national identity was in fact built on a basis of exclusion of different national and ethnic groups rather than creation of any platform for cultural integration.

The argument presented in this article is based on a research executed for a PhD thesis entitled "Od solidarycy do TypoPolo. Typografia jako obszar negocjowania tozsamosci zbiorowych po polskiej transformacji ustrojowej" ("From solidaryca to TypoPolo. Type design as a platform for negotiating collective identities in Poland after 1989") defended in the Institute of Ethnology and Cultural Anthropology, University of Warsaw in 2015. The thesis has been published under the title "Od solidarycy do TypoPolo. Typografia a tozsamosci zbiorowe w Polsce po roku 1989" (Szydłowska 2018). For this particular argument the research was based on a critical discourse analysis of historical texts, especially discussions in trade magazines as well as descriptions of Antykwa Półtawskiego typeface, which reveal its design principles and discuss them in the context of national values. The discourses found in the examined texts have been interpreted in the context of national ideologies in Poland and Central Europe in 19th and early 2oth century, which had presumably informed the national character of discussions and design proposition in question. The second interpretation tool has been a contemporary literature on nations and nationalisms, especially theories that discuss a "banal" or "everyday" nationalism (Billig 1995). The national discourse around type design has also been analysed by comparing the design principles of Antykwa Półtawskiego with contemporary examples of national typefaces for latin scripts namely the Irish Gaelic script and German Blackletter. 


\section{National typeface for Polish language}

A mission to design a national typeface seems obvious since the Polish national identity has been commonly based on a distinct, national language. In this context authors and editors of a trade magazine, "Grafika Polska" (Polish Graphic Art) proclaimed in 1921 that a matter of creating a Polish type is "one of the most urgent ones" (Szydłowska 2018, p.101). A discussion on a possible design of such typeface therefore began, engaging designers, bibliophiles and printers. The emergence of creating Polish typeface had been raised as soon as in 1823 by an eminent intellectual, Joachim Lelewel who noticed that Polish texts set in a foreign typeface look different from texts in other languages and came to a conclusion that none of imported typefaces is suited to Polish language therefore we need our own letters (Lelewel 1823, pp.230-23). In fact, until 1920s Poland didn't design nor produce any original typefaces and the print industry was based on imports complemented with some letters with diacritics, which are specific for the language (Szydłowska, Misiak 2015). Lelewel's observation was however too general to become a starting point for any specific guidelines on how to design the Polish typeface.

Figure 1 Sample text translated to English, Italian and Polish and set in Times New Roman. Differences in the column appearance are visible.

\begin{abstract}
The installation positions a forgotten and oft-despised hero of our daily life the mushroom - in the spotlight. It talks of it, yet does not show it. After all, we ourselves usually do not see fungi either, although we breathe in thousands of their spores every minute. Also, we rarely stop to consider the fact that relations entered into by representatives of the kingdom with other species are usually based on co-operation, love, and trust. Ninety percent of plants form a symbiosis with fungi, frequently allowing them into locations as intimate as the interior of their own cells - a relation much closer than that bonding the Homo sapiens to his or her microbiome. A plant would share carbohydrates with its partner, receiving nutrients and water in exchange. Can we imagine man in such a close relationship with any other species?
\end{abstract}

Protagonista dimenticato e spesso disprezzato nella nostra quotidianità, il fungo rappresenta dunque il soggetto centrale dell'esposizione, pur senza essere mostrato in maniera diretta. Dopotutto noi stessi non prestiamo molta attenzione ai funghi, pur inalando ogni minuto migliaia delle loro spore. Inoltre, raramente ci rendiamo conto che le relazioni che i rappresentanti di questo regno intrattengono con altre specie, molto spesso si basano su principi di collaborazione, amore e fiducia. Il $90 \%$ delle piante, ad esempio, entra in simbiosi con i funghi permettendogli di arrivare in luoghi molto intimi, come l'interno delle loro stesse cellule - una relazione assai più stretta di quella che unisce l'Homo sapiens al suo microbioma. Con questi partner, le piante scambiano zuccheri e ricevono in cambio acqua ed elementi nutritivi. Siamo in grado di immaginarci una relazione cosi stretta tra l'essere umano ed il rappresentante di un'altra specie?

Instalacja stawia w centrum zapomnianego, często pogardzanego bohatera naszej codzienności: grzyba. Mówi o nim, choć go nie pokazuje. My też przecież zwykle nie widzimy grzybów, choć z każdą minutą wdychamy tysiące ich zarodników. Rzadko też myślimy o tym, że relacje, w które wchodzą przedstawiciele tego królestwa z innymi gatunkami są najczęściej oparte o współpracę, miłość i zaufanie. $90 \%$ roślin wchodzi w symbiozę z grzybami często dopuszczając je do tak intymnych miejsc, jak wnętrza własnych komórek. To dużo bliższy związek niż ten, który łączy homo sapiens z jego mikrobiomem. Roślina dzieli się ze swoim partnerem cukrami, a ten odpłaca się substancjami odżywczymi i dostępem do wody. Czy jesteśmy w stanie wyobrazić sobie człowieka w tak bliskiej relacji z innym gatunkiem? 
It was probably a political or linguistic problem for Lelewel rather than a design-related one. Columns set in different languages never look alike. Languages differ one from another when it comes to word lengths, frequency of individual letters and so on. The question if a text set in Polish looks worse than a text set in English or French is a matter of taste. Lelewel didn't value the aesthetics of columns, he just observed that the foreign typefaces are not suitable for Polish language. It might have been a matter of politics: if we have a distinct language therefore we should have distinct letterforms as well. He might have also referred to the problem of diacritics. Polish is a Slavic language. Along with other West Slavic language (Czech and Slovak for instance) and some of the South Slavic languages (such as Croatian) it uses the Latin writing system. East Slavic and most of the South Slavic languages use Cyrillic script. Some of the languages, such as Serbian, use both scripts depending on the religious ideological choices. This division can be roughly explained by religious, therefore cultural choices different groups had made in the history. Groups who decided to adopt the Western cultural model (including Catholicism) are those who use Latin script while the ones who had decided to follow the Orthodox church, use the Cyrillic script. The fact is that most sounds, which appear in Slavic languages, can be easily noted using the Cyrillic script, whereas application of the Latin script for the purpose of the said languages has proven problematic. Therefore the Slavic languages, which use the Latin script, have employed different diacritic marks used to denote the sounds specific for them (such as $\int, \stackrel{r}{i}, z$ or 6$)$. The evolutions of different languages have resulted in applying different diacritic marks to denote similar sounds. The correct design of specific diacritic marks and Polish characters within an already existing typeface has always been a challenge but it doesn't mean that the language needs a distinct typeface. It's probable that on the 19th century typesetting market the Polish characters were usually designed without a proper care and that could have had been a reason for Lelewel's conclusion about the incompatibility between Polish language and foreign types.

Figure 2 A sample sentence used by type designers to check if the Polish characters work well in a given font. In this sentence all existing Polish characters appear and they are marked in red. The text is set in Times New Roman. The pronunciation of the sentence is following: zazuuwtढ gẽ̋lõ jaz̧

\section{Zażółć gęślą jaźń}




\section{National typefaces for Latin script}

A comparison with two cases of existing European, Latin national typefaces indicate that there hadn't been any successful attempt to design and implement any national letters build from scratch. Both Gaelic letters specific for Ireland and Blackletter, which was connected with Germany had been created organically with no attempt to design them for national purposes. The national connotations of these styles were imposed later when both nations appropriated them as tokens for a national cause. From the very beginning an opposition between Blackletter and roman typeface has been inscribed into a cultural model which has imposed discursive frames useful to set the boundaries between two cultures: Germanic and Romanic (Shaw, Bain 1998, pp.12-13). They employed dichotomies: Middle Ages vs. modernity, Protestantism vs. Catholicism, romanticism vs. Enlightenment, mysticism vs. rationality, etc. According to Shaw and Bain (1998, pp.12-13), an initial attribution of Blackletter to Germany had been a matter of taste and prestige. It was only during the Napoleonic wars when French army invaded Germany that these two cultural models (i.e. Germanic and Romanic) become antagonised. As a result, the national dimension of Blackletter has been highlighted. Aforementioned Johann Gottfried Herder has provided an ideological foundation of such attribution and his vision of an organic nation integrated by a common culture (Mirsky 1998, p.7). Since Herder put special emphasis on a national language, it was logical that a style of writing used to record the language has been given a national dimension. National typeface as a political tool was also the case of Gaelic typography in Ireland (Staunton, Decottignies 2010; Staunton 2005; Staunton 2006). First unsuccessful attempt to create an Irish typeface was undertaken by the queen Elisabeth I as a tool for colonisation. Her idea was to distribute Irish translations of protestant religious books in this catholic country. The attempt failed due to insufficient effort and expertise. The following chapters of the history of Gaelic type are connected with the aspects of resistance and national revival. First Gaelic typefaces were created by exiled Irish catholic monks who found asylum in France and Italy (Staunton 2005, p.87). Then the job has been taken over by artists, intellectuals, historians and antiquaries in 19th century as a part of a pan-European movement of national revivals (Staunton 2006, pp.144-146).

None of these cases could serve as a model for creating a national typeface from scratch. Both of them were based on handwriting found in manuscripts. In case of Blackletter, it was a style widely used all over Europe in the late Middle Ages. Gaelic type was based on a style found in early Christian codexes produced in Ireland, such as "Book of Kells“, adapted to a specificity of Irish orthography. Polish designers and printers faced thus a challenge of inventing a useful yet distinct typeface with some clear national traits. When the discussion started in 1921 none of the experts had any idea how the Polish typeface 
should look like nor they knew how to start a proper research. The printers, artists, bibliophiles and typographers who participated in the discussions didn't take into consideration the typographic or linguistic problems whatsoever. During following years a number of articles was written discussing the methodological, artistic and ideological aspects of the undertaking. Some authors proposed vernacular inspirations but soon realised that it wouldn't lead to designing anything useful. Apparently highly decorative vernacular elements were unsuitable as a source for designing a modern, functional text typeface. Other authors published some abstract formulas deduced from general rules of the construction of letters. Further investigations proved equally unproductive. The idea of a Polish typeface resulted to be very abstract, with a clear political and cultural significance but with no reference to the actual type design-related problems.

\section{The ultimate national typeface: Antykwa Półtawskiego}

Finally a typographer, Adam Półtawski approached the subject and started his research. At the beginning he had no idea how to start the quest either. He began with studying manuscripts and old prints but it was a road to nowhere. Then he turned to a similar observation Joachim Lelewel had had one hundred years before: that the column of a text set in Polish looks different from a column set in an other language. He compared both columns and decided that the Polish one looks bad because its greyness was not even. According to Półtawski, a frequent use of letters with diagonals (such as "w", "k", "y", "z") was to blame. The result was an unwanted blank space between two neighbouring letters with diagonals, which gave an impression of an additional spacing. To solve this problem Półtawski decided to replace diagonals with more rounded shapes and to thicken the vertical strokes (Sowiński 1988, p.193). The result was a publication of Antykwa Półtawskiego, a classical roman typeface adapted to the specificity of Polish language and probably the most widely used Polish typeface of the 2oth century. With the accomplishment Półtawski managed to bring together modernity (the typeface was legible, useful and suitable for a variety of purposes) with the affirmation of national identity. Antykwa Półtawskiego got proper recognition very soon and the authors who previously had discussed on the nature of Polish typeface enthusiastically praised the successful accomplishment of the mission. The rational, justified by the anatomy of the letters and the quality of the typography solutions proposed by Półtawski were an ultimate answer to the question of a Polish typeface although at the beginning nobody knew how it should look like. We can conclude that Półtawski has first invented the design problem (uneven greyness of a column) and then he solved it. In other words, he created a functional solution to a symbolic problem. 
Figure 3 Adam Półtawski, Antykwa Półtawskiego, 1928. The digital font was created by Bogusław Jackowski, Janusz M. Nowacki and Piotr Strzelczyk (JNS TEAM). Photo credit: SVG from Lumu (talk) - Polish TeX Users Group; SVG self created using pdfeTeX from LaTeX source, CC BY-SA 3.o.

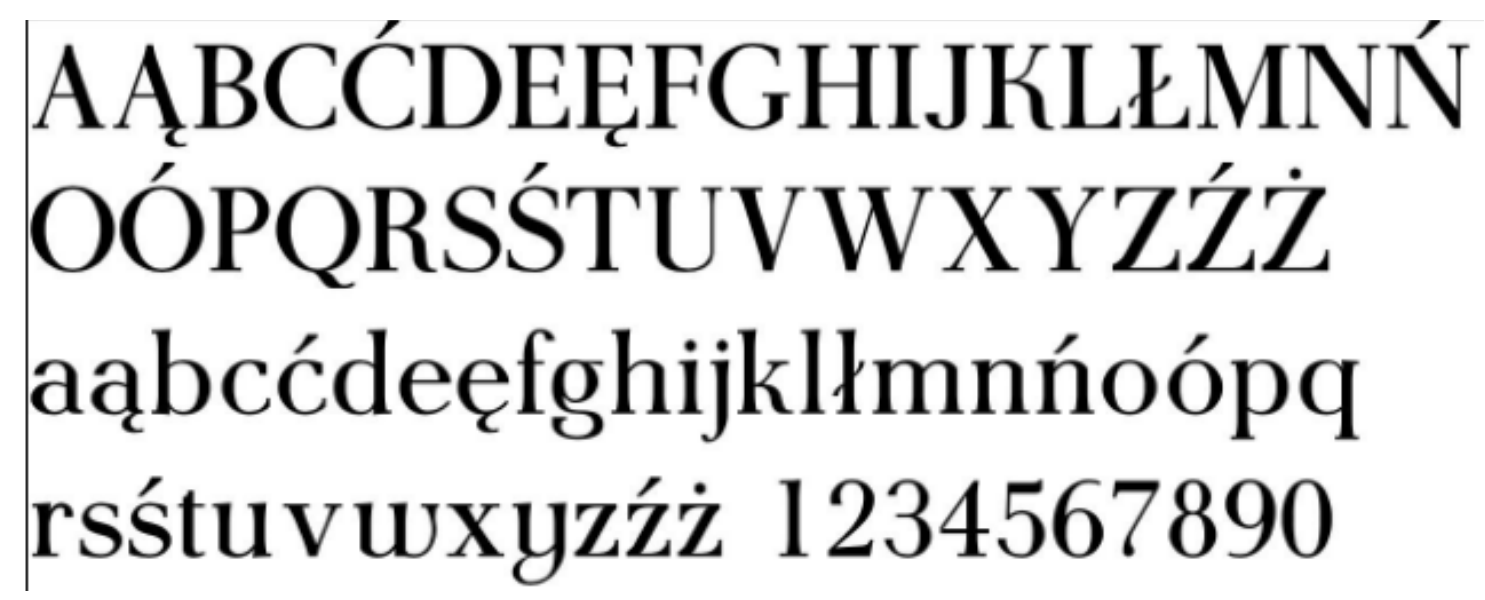

Although, at the very beginning, Antykwa Póltawskiego aimed at representing an abstract idea of the nation rather than solving any problems of the specific language it eventually became based on the language as a token of the national identity. The identification of a language and a nation can be attributed to the ideas of Johann Gottfried Herder, which could prevail along with the neo-romantic ideas in Polish inter-war culture. It can also be explained by a common sense connection between a language and a nation. Michael Billig (1995, p.29) expresses criticism towards those social scientists that assume that "those speaking the same language are liable to claim a sense of national bond". Taking relationship between an official language and a dialect as an example he argues that defining language boundaries is necessarily connected with power relations and a "dialect" is "frequently a language which did not succeed politically" (Billig 1995, p.32). Languages, boundaries between them and their hierarchies are thus the same constructs as nations and there is nothing natural in identifying state borders with the borders of languages' reach. Billig writes: "More is at stake in drawing the boundary of a language than linguistics. The battle for hegemony, which accompanies the creation of states, is reflected in the power to define language (...)" (Billig 1995, p.32). Although Billig refers mainly to power relations between different groups which use different languages where those who are in power claim the right to define their language as official and legitimate and other languages as "dialects", his observations inspire to question the naturalness of the association between a language and a national identity when we speak about creating a national typeface. Focusing on the aspect of power relations, it is justified to ask a question about a privilege and its lack when it comes to writing systems. 


\section{Different scripts in Poland}

The fact that Antykwa Półtawskiego was based on the language was politically important for at least two reasons. First of all, it was useful in the context of above mentioned "identity politics" and cultural diplomacy. The newly formed state was composed of areas, which by 1918 didn't have much in common: starting from the level of industrialisation, through architecture to end with a degree of civilizational development. Language was in fact one of few elements inhabitants of those terrains had in common and during the 130 years of "partitions" the intelligentsia had done its best to preserve elements of national identity grounded in culture. Secondly, the new Polish citizens were members of groups, which until mid 19th century were regarded as being of different ethnicities. The dominant groups of gentry and aristocracy were keen to exclude peasantry from a national community to welcome it as soon as it was needed to fight with the invaders (Klekot 2016, p.150). So the citizens of the newly proclaimed state had in fact a very weak sense of a shared national identity and the idea of constructing the identity based on the language everyone shared seemed reasonable. The problem was the fact that the interwar Poland was inhabited by different ethnic groups who had lived there "since always" (Jews) but kept their strong and distinct identity or appeared in Poland as a consequence of the country's own colonising undertakings (namely the subjugation of the territories east from Poland). These groups used different scripts from Latin on a daily basis: Hebrew (for Yiddish speaking Jews) or Cyrillic (for Orthodox groups of Ukrainians among others). The foundation of the national typeface on the Latin script - intentionally or not - excluded from the national community people whose first script was different. It can therefore be interpreted as an act of drawing language boundaries mentioned by Billig, but this time within one country, which tried very hard to be perceived as coherent and distinct. At the same time, Poland wanted to be regarded as modern and belonging to a broader cultural community of Western Europe, which shared Enlightenment values and was an heir of western, Romanic tradition. It was a matter of ambitions and distancing itself from the recent oppressors (Russia, Germany), which used letters different from roman and Latin (Cyrillic and Blackletter, accordingly). That's why Antykwa Półtawskiego (antykwa means roman typeface in Polish) was not only a national typeface, but also a typeface based on good old roman letters.

\section{Conclusion}

Antykwa Półtawskiego resulted as the most successful response to the appeal for designing a national typeface. The need was derived from political and cultural reasoning and - to a smaller extent from the specificity of Polish language that uses diacritic marks in its 
written form. The political significance of a national script was mainly connected with a cultural diplomacy: an attempt co create a modern but original image of the nation-state. It was believed that presenting Poland as a modern country with a distinct and unique culture could help in preserving independence which - just after the World War First - was still unstable. Members of the intelligentsia at home believed that creating a common ground of a widely accepted national culture could help in integrating different groups who had lived within different states before 1918. It also referred to different social classes. As the peasantry had been regarded as a different ethnic group, its inclusion into the national community was vital if the elites wanted to count on its allegiance when it comes to the national cause. However creating a national typeface from the scratch proved to be a difficult challenge and it remained only a political and cultural idea with no type design-related solutions for years. Examples from different nations and their national typefaces (Germany and Blackletter, Ireland and Gaelic script) show that associating given typographic styles with nations has usually been long processes connected with various political and cultural circumstances. Finally a typographer, Adam Półtawski, presented a satisfying answer to the appeal for a Polish typeface. He grounded his investigations in observations about an appearance of a column set in Polish and came to the conclusion that in order to make a column of a Polish text look more even (i.e. better) one has to redesign letters with diagonals. My argument is that Półtawski found a functional and type design-related solution to a political problem and that the observations about the specificity of a Polish written and printed language were secondary to the political need to design a national typeface. I claim that the crucial decision Adam Półtawski made when it comes to the identity was a selection of a serif roman typeface. This way he confirmed that Poland had been a part of the Western civilisation in its Romanic, Enlightenment version. It meant distancing the nation from both the Germanic and Eastern, Russian tradition. Both of the countries, Russia and Germany, had been the political adversaries of Poland back in the early 2oth century. But the community built on the basis of common typeface and - as a result - common script was also a community which excluded different ethnic and religious groups which existed in Poland between the wars: Jews who used Hebrew script and the orthodoxies (especially Ukrainians) who used Cyrillic script.

\section{References}

Billig, M. (1995). Banal Nationalism. London, Thousand Oaks and New Delhi: Sage Publications.

Chmielewska, A. (2006). W słuzbie panstwa, społeczenstwa i narodu. „Panstwowotwórczy” artysci plastycy w II Rzeczypospolitej. Warszawa: Wydawnictwo Instytutu Filozofii i Socjologii PAN. 
Crowley, D. (2001). Finding Poland in the Margins. The Case of the Zakopane Style. Journal of Design History, v.14, n.2.

Crowley, D. (1992). National Style and Nation-State: Design in Poland from the Vernacular Revival to the International Style. New York and Manchester: St. Martin's Press, Manchester University Press.

Gimeno-Martínez, J. (2016). Design and National Identity. London and New York: Bloomsbury.

Jedlicki, J. (1991). Polskie koncepcje kultury rodzimej (1900-1939). Kultura i społeczenstwo, n.2.

Klekot, E. (2016). Etnodizajn - polskie gry z nowoczesnoscia. Herito, n.24.

Lelewel, J. (1823). Bibliograficznych ksiag dwoje. T.1. Wilno.

Mirsky, L. (1998). The Crystalline Plant. In Shaw, P. \& Bain, P. (Eds.) Blackletter: Type and National Identity. New York: Princeton Architectural Press.

Shaw, P. \& Bain, P. (1998). Blackletter vs. Roman: Type as Ideological Surrogate. In Shaw, P. \& Bain, P. (Eds.) Blackletter: Type and National Identity. New York: Princeton Architectural Press.

Sowinski, J. (1988). Adam Półtawski. Typograf artysta. Wrocław: Wydawnictwo Ossolineum.

Staunton, M. \& Decottignies, O. (2010). Letters from Ankara. Scriptal Change in Turkey and Ireland in 1928. In Gillissen, C. (Ed.) Ireland: Looking East. Brussels: Peter Lang.

Staunton, M. (2005). Trojan Horses and Friendly Faces: Irish Gaelic Typography as Propaganda. Revue LISA/LISA e-journal, v.3, n.1.

Staunton, M. (2006). Types of Irishness. Irish Gaelic Typography and National Identity. In Genet, J.; Mikowski, S \& Garcier, F. (Eds.) The Book in Ireland. Newcastle: Cambridge Scholars Press.

Szczerski, A. (2010). Modernizacje. Sztuka i architektura w nowych panstwach Europy Srodkowo-Wschodniej 1918-1939. Łódz: Muzeum Sztuki.

Szydłowska, A. \& Misiak, M. (2015). Paneuropa, Kometa, Hel. Szkice z historii projektowania liter w Polsce. Kraków: Wydawnictwo Karakter.

Szydłowska, A. (2018). Od solidarycy do TypoPolo. Typografia a tozsamosci zbiorowe w Polsce po roku 1989. Wrocław: Wydawnictwo Ossolineum.

\section{Author:}

\section{Dr. Agata Szydłowska}

agata.szydlowska@asp.waw.pl

Chair of Design History and Theory

Faculty of Design, Academy of Fine Arts in Warsaw

ul. Mysliwiecka 8, o0-459, Warsaw, Poland

Paper submitted on 11/04/2019

Approved on 28/07/2019 